\title{
A MULHER CRUEL ATRAVESSA OS TEMPOS: MEDEIA, O FENÔMENO TRÁGICO E O CINEMA
}

\author{
THE CRUEL WOMAN CROSSES TIME: MEDEA, THE \\ TRAGIC PHENOMENON AND THE CINEMA
}

Suzane Morais da Veiga Silveira

Resumo: Este artigo tem por objetivo investigar a ressonância do mito de Medeia, a
partir da versão criada por Eurípedes (também grafado Eurípides; do grego antigo:
Eủpı í$_{\delta} \uparrow$ ), em $431 \mathrm{AC}$, no cinema do século XX, que problematiza essa figura feminina
enquanto paradigma de mulher cruel e passional. Nesse sentido, elaboramos um
estudo sobre a produção cinematográfica Medea (1969), feita pelo diretor italiano Pier
Paolo Pasolini, que propõe uma releitura da personagem, a qual, no longa-metragem,
é interpretada pela cantora lírica Maria Callas. Assim, examinamos como se processa
o fenômeno trágico na composição da protagonista e no desenvolvimento da trama.
Como metodologia, realizamos uma análise comparativa da Medeia euripidiana e a
personagem homônima de Pasolini, a partir de fundamentação teórica composta por
Aristóteles et al. (2002), Junito de Souza Brandão (1984), Massimo Fusillo (1996), Albin
Lesky (1990), Ulysses Maciel (2011) e Ryan-Scheutz (2007).

Palavras-chave: Medeia; cinema; Pasolini.

\begin{abstract}
This article aims to investigate the resonance of the Medea myth, based on the version created by Euripides (from Ancient Greek: Ev̉pı $\pi i \delta \eta \zeta)$ ), in $431 \mathrm{BC}$, in the $20^{\text {th }}$ century cinema, which questions this female figure as a paradigm of passionate and cruel woman. In this sense, we elaborated a study of the cinematographic production Medea (1969), made by the Italian director Pier Paolo Pasolini, which proposes a rereading of the character, who, in the feature film, is played by the lyric singer Maria Callas. Thus, we examine how the tragic phenomenon occurs in the composition of the main character and in the development of the plot. As methodology, we conducted a comparative analysis of the Euripidian Medea and the homonymous character of Pasolini, based on a theoretical foundation composed by Aristotle (2002), Junito de Souza Brandão (1984), Massimo Fusillo (1996), Albin Lesky (1990), Ulysses Maciel (2011) and Ryan-Scheutz (2007).
\end{abstract}

Keywords: Medea; cinema; Pasolini.

\footnotetext{
"Doutoranda em Literatura Brasileira pelo Programa de Pós-Graduação em Letras Vernáculas da Universidade Federal do Rio de Janeiro (UFRJ). Integrante do Núcleo Interdisciplinar de Estudos da Mulher na Literatura (NIELM). E-mail: suzanesilveira@letras.ufrj.br.
} 


\section{CoNSIDERAÇões INICIAIS}

"O coração tem razões que a própria razão desconhece."

Blaise Pascal

O mito de Medeia serviu de tema para diversas obras artísticas e literárias ao longo da história da arte ocidental, devido à perplexidade que a cruel personagem provoca em nosso imaginário. O texto de Eurípedes, versão mais conhecida e também mais sombria dessa figura trágica, foi escrito e encenado pela primeira vez em 431 A.C, sendo, desde então, retomado por diversos autores teatrais, que procuraram dar nova voz à protagonista. De fato, houve na cena nacional várias releituras de Medeia, realizadas por diretores e grupos renomados como Denise Stoklos, Jorge Takla e Consuelo de Castro, Regina Galdino, Luciana Saul, o Grupo Odradek, entre outros. No século XX, o fascínio exercido por Medeia ganhou também o cinema, recebendo diversas adaptações cinematográficas, dentre as quais a do diretor italiano Pier Paolo Pasolini, que é o objeto de nosso estudo.

Assim, temos por objetivo analisar a caracterização de Medeia no filme ítalo-franco-germânico Medea, de 1969, dirigido por Pasolini e estrelado pela cantora lírica Maria Callas, investigando como se processa o fenômeno trágico na composição da personagem principal e no desenvolvimento da trama. Nesse sentido, percebe-se que, ao adaptar Medeia para o cinema, o diretor italiano não se fixou no texto de Eurípedes, mas extraiu dele somente o que tinha de sentido trágico. Segundo o próprio diretor em entrevista para um extra do filme, o seu intuito era traduzir o mito para pensar o conflito existencial do homem moderno:

me limitei a retirar do texto de Eurípides apenas algumas citações... Medeia é o confronto do universo arcaico e clerical com o mundo de Jasão, mundo racional e pragmático. Jasão é o herói atual, que não apenas perdeu o senso metafísico como sequer se questiona sobre isso. A sua procura busca apenas o sucesso. Confrontado à outra civilização, à raça do espírito, Jasão dá início a uma tragédia impressionante. ${ }^{1}$

Desse modo, o texto de Eurípedes serve como base para uma releitura do paradigma da mulher cruel e passional, que leva às últimas consequências o seu amor e ódio pelo argonauta Jasão, presente no texto do autor grego. Entretanto, como percebemos na citação, Pasolini direciona o foco para discutir o embate entre um mundo arcaico, centrado nos rituais da natureza e do sagrado - representado pela sacerdotisa Medeia - e um pensamento moderno e racional - ligado à figura do argonauta Jasão -, que perdeu os laços metafísicos com o universo simbólico do mundo antigo. Assim, ao elaborar o roteiro do longa, o diretor italiano

${ }^{1}$ Medea. Direção e roteiro: Pier Paolo Pasolini. Produção: San Marco SpA (Roma), Le Films Number One (Paris) e Janus Film und Fernsehen (Frankfurt). Atores: Maria Callas (Medeia), Guiseppe Gentili (Jasão), Laurent Terzieff (centauro), Margarethe Clementi (Gláucia), Massimo Girotti, Paul Jabor, Vladimir Julukhadze, Udo Kier, Gerard Weiss, Luigi Barbini, Paul Jabara, Anna Maria Chio. Produtores: Franco Rossellini; Marina Cicogna. Fotografia: Ennio Guarnieri. Edição: Nino Baragli. Desenho de Arte: Nicola Tamburro. Figurino: Piero Tosi. Filmado em maio-agosto 1969. Duração: 110 min. 
aproveita a própria estrutura da tragédia construída pelo dramaturgo grego que, conforme nos mostra Junito de Souza Brandão (2011), não mais está atrelada ao mito propriamente, mas ao coração humano:

[...] Eurípedes há de conceber a tragédia como uma práxis do homem, operando, por isso mesmo, uma profunda dicotomia entre o mundo dos deuses e o mundo dos homens. É que para o poeta de Medéia, o "Kósmos" trágico não é mais o mito, mas o coração humano, ao qual o grande poeta desceu como se fora um mergulhador e de lá arrancou a tragédia (BRANDÃO, 2011, p. 71).

A partir dessa visão do fenômeno trágico, Pasolini parece atualizar o mito, com uma nova proposta de colocar a personagem Medeia no centro irradiador da problemática em torno do embate entre passado e presente, primitivo e moderno, arcaico e contemporâneo. Com isso, procura mapear a influência e a permanência do mito como elemento de angústia existencial do ser humano, conforme assegura o próprio cineasta: "A incerteza existencial da sociedade primitiva permanece como categoria da angústia existencial ou da fantasia da sociedade evoluída"2 (PASOLINI, 2001, tradução nossa). Para isso, Pasolini recorre a um método de filmagem não convencional em que são privilegiados alguns signos criados por ele para representar esteticamente, em sua obra fílmica, os elementos trágicos que conferem à personagem Medeia o seu caráter mítico permanente.

Podemos perceber, durante o filme, imagens que desfazem ou deslocam a sequência da "trama" da tragédia euripidiana para o campo subjetivo das emoções e dos conflitos da personagem principal, pois o que importa ao diretor é acentuar a desgraça vivida por Medeia e não a sucessão dos acontecimentos propriamente. Dessa forma, recursos visuais e sonoros são utilizados para dar vida ao embate interior da protagonista, como: os longos closes do rosto de Medeia com voz em off, que aparecem de forma constante; a vida de Medeia anterior a Jasão, que é retratada com exaustão; bem como a música da trilha sonora, dentre outras técnicas, foram escolhidas para ressaltar a opção do diretor em tematizar o sofrimento da princesa da Cólquida. Assim, o diretor italiano introduz signos fílmicos - imagens e sons que, extrapolando os significados contidos no texto dramático de Eurípedes, apontarão para uma nova forma de obra dramática, conforme explicita Ulysses Maciel em Medéia de Pasolini, uma tradução desconstrutora (2011): "A entrada em cena desses signos fílmicos possibilitará o preenchimento de lacunas deixadas pelo texto poético, assim como pelas suas sucessivas interpretações" (MACIEL, 2011, n.p.).

${ }^{2}$ No original: "L'incertezza esistenziale della società primitiva permane come categoria dell'angoscia esistenziale o della fantasia della società evoluta”. 
Figura 1: Capa de divulgação do filme Medea

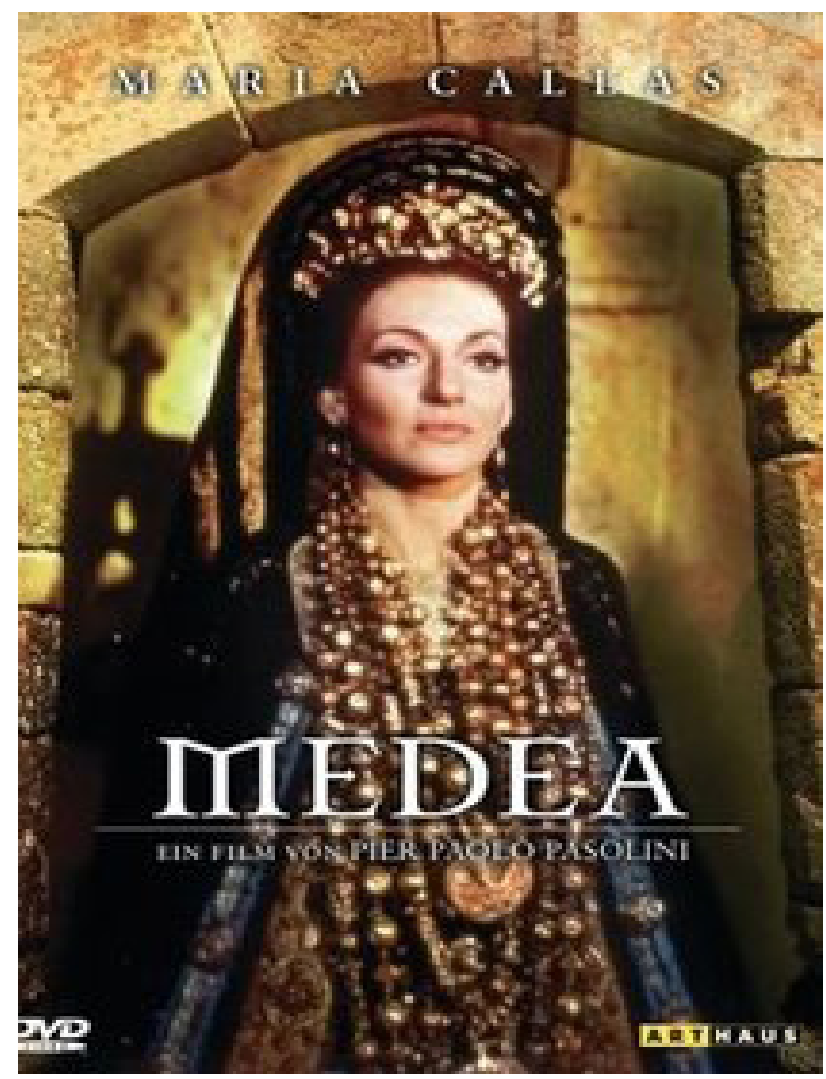

Fonte: http://www.adorocinema.com/filmes/filme-512/

\section{A tRagédia ENQUANTO GÊNERO E O FENÔMEO TRÁGICO EM MEDEIA, DE EURÍPEDES}

de acordo com Aristóteles et al. (2005), a arte seria o resultado da imitação da realidade, cuja derivação dá ao teatro (tragédia) a dupla função de representar o real: "É a tragédia a representação duma ação grave, de alguma extensão e completa, em linguagem exornada, cada parte com o seu atavio adequado, com atores interagindo, não narrando, a qual, inspirando pena ou temor, opera a catarse própria dessas emoções" (ARISTÓTELES ET AL., 2005, p. 24, tradução de Jaime Bruna). O autor de Arte Poética ainda define conceitos basilares para se entender, em um primeiro momento, os elementos referentes à constituição da tragédia enquanto gênero, sendo os principais a hybris, a peripécia, o reconhecimento e a catarse.

A hybris compreendendo a desmedida, o erro (ou sucessão de erros) cometido pela personagem, o qual poderá desencadear a peripécia, que é "uma reviravolta das ações em sentido contrário [...] segundo a verossimilhança ou necessidade" (Idem, p. 30), ao que se segue a descoberta do erro, por parte do herói: "O reconhecimento, como a palavra mesma indica, 
é a mudança do desconhecimento ao conhecimento, ou à amizade, ou ao ódio, das pessoas marcadas para a ventura ou desdita (Idem). Esse processo leva ao fim trágico e à catarse, o fim último da tragédia grega, que significa a purificação das emoções por meio da empatia do leitor/espectador com os sentimentos de terror e de piedade suscitados pelo desenrolar das ações.

Ao analisarmos a concepção de Aristóteles sobre o gênero tragédia, percebemos que ele apenas esboça o que seria o fenômeno trágico, ou antes aponta apenas um aspecto de sua manifestação, limitando-se a descrever o que ele percebia, na observação atenta das peças realizadas na Grécia, os elementos necessários ao "sucesso" de uma peça trágica. Ora, podemos aferir que, nessa perspectiva, a tragédia e o trágico são conceitos distintos, e que, para o filósofo, a tragédia baseia-se essencialmente na provação do herói, e em sua hamartía - isto é, falta, erro, desmando - fruto das paixões. Porém, segundo nos aponta Vanessa Pinheiro, leitora de Peter Szondi, em O trágico e o demoníaco em O Evangelho Segundo Jesus Cristo,

A tragédia, no entanto, se extinguiu ainda no século V A.C., o que permaneceu e transpassou os séculos foi o sentimento trágico, embora tenha mudado sua concepção original. Na Atenas inquieta a partir da influência sofística, desestabilizada pelos trinta penosos anos de guerra com Esparta e invadida pelos romanos, não havia mais espaço para o repercutir do gênero. Se ainda houvesse, o advento da religião cristã não permitiria. Afinal, as culpas trágicas, inocentes e hereditárias, virariam pecados de fundo moral, e o destino (moira) não mais seria determinante, visto que o Deus cristão, diferentemente do Zeus olímpico, teria dado ao ser humano total autonomia e livre-arbítrio e haveria de recompensá-lo por sua obediência (PINHEIRO, 2007, p. 10, grifo nosso).

Assim, é possível perceber que, para o diretor Pier Paolo Pasolini, foi mister sondar o sentimento trágico inspirado pela tragédia de Eurípedes, e que sobreviveu ao tempo depois de tantos séculos, suscitando temor nos leitores da peça. Dessa maneira, o diretor confere novo significado à vivência do conflito trágico humano no filme, uma vez que aponta para um campo discursivo autorreferencial, ao contrapor a visão do que seria o mito hoje e sua representação no cinema. Cria, assim, um paradoxo entre o mítico e o moderno, redefinindo mesmo o fenômeno trágico que deixa de ser apenas a experiência da piedade e do terror, e passa a ter uma dimensão histórica e crítica. Para Maciel (2011), Medea de Pasolini realiza uma leitura dialética do trágico, conectando significados contrários: "o conflito entre a natureza mítica de Medéia e a razão moderna (o Jasão de Pasolini somos nós) tira do terreno da análise textual a vivência, pelo espectador, do fenômeno trágico, conferindo-lhe dimensão histórica, atualizadora" (MACIEL, 2011, n.p.).

O trágico assume perante os críticos uma variada gama de conceituações e manifestações, sendo sua definição de difícil consenso entre os autores que escrevem sobre o tema. De acordo com Peter Szondi (2004), em Ensaio sobre o trágico, não haveria uma definição única e 
universal do trágico devido ao seu próprio caráter dialético. Ele acredita, assim, que "não existe o trágico, pelo menos não como essência. O trágico é um modus, um modo determinado de aniquilamento iminente ou consumado" (SZONDI, 2004, p. 84). Na visão de Schelling (2001), o trágico encontra-se em um embate entre dois lados opostos, centrado na oposição liberdade/ necessidade, explicitado quando o herói percebe o (alto) preço pago por sua liberdade, vendo-se, a um só tempo, vencido e vencedor: "O essencial da tragédia é, portanto, um conflito real entre a liberdade no sujeito e a necessidade, como necessidade objetiva" (SCHELLING, 2001, p. 316). Entretanto, para Schelling (2001), a tragédia seria um agente unificador dessa dualidade, quando, por exemplo, a personagem Édipo, na famosa peça de Sófocles, após se descobrir como o menino da profecia (que mata o pai e casa com a mãe) admite ser o autor dos atos, assume as consequências, aceita o seu destino e escolhe livremente receber o castigo inevitável: "O maior pensamento e a maior vitória da liberdade é suportar voluntariamente também um crime inevitável, para assim, na perda de sua própria liberdade, demonstrar essa mesma liberdade e sucumbir, porém, ainda com uma declaração de sua vontade livre (SCHELLING, 2001, p. 318). Portanto, no pensamento do autor acerca da tragédia, há uma superação do binarismo liberdade/necessidade, uma vez que a imposição do destino trágico não exclui o componente de liberdade humana, o que transforma a existência dessa dualidade em unidade, ou o que Schelling denomina de indiferença.

Hegel (1993), na sua Estética, examina a tragédia dentro de um sistema de artes, enquanto figura de expressão artística, ou uma etapa na caminhada do espírito, sendo um estágio do movimento dialético, que é marcado pela dimensão do conflito. Essa concepção traz uma nova leitura para o trágico, pois explicita que a noção de consciência, como a compreendemos hoje, não estava presente nas tragédias antigas, ou seja, não havia uma moralidade dos costumes, mas sim uma eticidade nos hábitos tradicionais fundantes das instituições sociais na antiga Hélade. Esse entendimento marca a diferença entre as tragédias antigas e as modernas, nas quais existe a subjetividade nas ações das personagens, que se encontram imbricadas no conflito entre os desejos e os ideais morais do indivíduo, revelando o seu embate psíquico: "o verdadeiro conteúdo da ação trágica e dos fins perseguidos pelos autores destas ações é fornecido por forças universais, que regem a vontade humana e se justificam por si mesmos: 0 amor carnal, o amor paternal e maternal; o amor filial; o amor fraternal [...]" (HEGEL, 1993, p. 647).

Na visão do filósofo Kierkegaard (2010), o trágico está ligado à existência humana em sua condição paradoxal, na dinâmica entre tragicidade e liberdade, pela consciência da possibilidade do risco, da tragédia. Há, pois, um sentimento trágico do existir que não consiste na mera fatalidade que resulta no desespero, mas na própria liberdade, que, a partir dessa visão, seria o núcleo irradiador do sofrimento e da angústia, quando o ser humano se percebe criador a partir de sua condição trágico-existencial de finitude: "A angústia é a vertigem da liberdade, que surge quando o espírito quer estabelecer a síntese, e a liberdade olha para baixo, para sua própria possibilidade, e então agarra a finitude para nela firmar-se" (KIERKEGAARD, 2010, p. 
66). Já Schopenhauer (2001), mais pessimista, faz uma leitura da existência humana como um amontoado de criaturas miseráveis, que se devoram mutuamente na esperança de aliviar os seus próprios sofrimentos. Logo, para o filósofo, a vida humana é trágica por excelência dado o absurdo da existência, em que os homens lutam desesperadamente pela própria sobrevivência. Assim, o intuito da tragédia seria o da expiação, tratando-se de mostrar "o espetáculo de um grande infortúnio" (SCHOPENHAUER, 2001, p. 267).

O pós-idealista Nietzsche (1992), em sua reflexão sobre a tragédia, desenvolve dois princípios: o apolíneo, que é a individuação, ou seja, a possibilidade de diferenciação, de criação: uma oportunidade dada ao homem para encontrar significado na vida, como experiência de medida, harmonia e consciência de si; e o dionisíaco, que é a possibilidade de escapar da divisão, da individualidade, e se fundir ao uno ou se integrar à totalidade, ao mesmo tempo que significa também desmesura, desmedida, abandono, a hybris. Para o filósofo prussiano, a tragédia não visa à eliminação da tensão e, com isso, a descarga aliviadora da catarse, mas o despertar do sentimento de tensão, de luta e confrontação dos poderes essenciais do ser, da vida, da existência, representada pela tensão entre o apolíneo e o dionisíaco, entre o todo e a sua fragmentação na aparência.

Segundo Albin Lesky (1990), em seu livro A Tragédia Grega, o trágico “é o que designamos por possibilidade de relação com o nosso próprio mundo. O caso deve interessar-nos, afetar-nos, comover-nos. Somente quando nos sentimos atingidos nas profundas camadas do nosso ser é que experimentamos o trágico" (LESKY, 1990, p. 33). Em seu estudo sobre o problema (de conceituação) do trágico, Lesky apresenta algumas características que o envolvem e possivelmente o distingue de outros conceitos. Primeiro define o trágico como "algo que ultrapassa os limites do normal" (Idem, p. 22). Depois, ao investigar poetas e escritores trágicos, notadamente Goethe, autoriza nas palavras do poeta a seguinte definição: "Todo trágico se baseia numa contradição inconciliável. Tão logo aparece ou se torna possível uma acomodação, desaparece o trágico” (GOETHE apud LESKY, 1990, p. 31).

Ao ler Aristóteles, Lesky (1990) apresenta outra "máscara" do trágico, seguindo a visão do filósofo grego, como a situação trágica do homem ou a "falha" na capacidade humana de reconhecer aquilo que é correto e obter uma orientação segura (LESKY, 1990, p. 27). Decorre daí a visão do trágico como mudança de ventura ou "a dignidade da queda" (Idem). Ocorre também de o autor conceituar o trágico como a sensação do Nostra res agitur (LESKY, 1990, p. 33), quando somos atingidos nas mais profundas camadas do nosso ser, perante a identificação com o sofrimento do sujeito do ato trágico o qual deve ter tudo à consciência, sofrer conscientemente.

Conforme ressalta Junito Brandão, "Medéia não é apenas a esposa sanguinária e vingativa, mas uma figura que personifica as forças cegas e irracionais da natureza” (BRANDÃO, 2011, p. 80). Ainda sobre esse tema, Albin Lesky afirma que, ao longo da ação dramática na tragédia, esquecemos a feiticeira e suas magias e nos voltamos para a esposa enganada, para 
a pessoa humana, para a mulher controlada por suas paixões e pelo pathos da dor, cruel e ressentida, que é capaz de assassinar os próprios filhos (LESKY, 1990, p. 171).

\section{Medéia}

Maior dos cínicos! (É a pior injúria que minha língua tem para estigmatizar a tua covardia!). Estás aqui, apontas-me, $\mathrm{tu}$, meu inimigo mortal? Não é bravura nem ousadia, olhar de frente os ex-amigos depois de os reduzir a nada! O vício máximo dos homens é o cinismo.

[...] sofrerás ouvindo-me. Começarei pelo princípio.

$\mathrm{Eu}$ te salvei (todos os gregos que embarcaram contigo na Argó bem sabem),

quando foste enviado para submeter

ao duro julgo o touro de hálito inflamado

e para semear a morte em nossos campos.

Fui eu que, oferecendo-te modos e meios

de matar o dragão, guarda do tosão áureo, imune ao sono, com seus múltiplos anéis,

[...] Traí meu pai, eu, sim, e traí a família

para levar-te a Iolco (foi maior o amor

que a sensatez); fiz Pelias morrer também.

(EURÍPEDES, 2004, p. 36-37, tradução de Miroel Silveira e Junia Gonçalves)

E seria nesse ponto justamente que se encontra o elemento trágico em Medeia, que tanto fascina e assombra, o infanticídio é cometido pelas mãos da própria mãe, ato de vingança desencadeado pela traição de Jasão e embasado por um contexto histórico - a vergonha sentida por Medeia, ao ser tranquilamente abandonada pelo homem a quem dera tudo de si perante todas as mulheres de Corinto e toda a sociedade ateniense. Segundo Eduardo Pereira Machado (2011, p. 134),

o trágico em Medéia está diretamente ligado às ações e reações das personagens, principiando pelo amor "desmedido" de Medéia, que, ao ser traída, transforma-se em ódio exacerbado. Medéia está ligada ao trágico, pois nos aproxima da realidade universal, configurando uma série de crimes passionais, movidos pelo ciúme e pela raiva, por meio dos quais destrói tudo e todos à sua volta. Jason é trágico pelo final irremediável: está sozinho, perdido, sem pátria. 


\section{O TRÁGICO EM MEDEA, DE PASOLINI}

Na Medea, de Pasolini, a protagonista parece incorporar um mundo arcaico e religioso, enquanto Jasão, ao contrário, é racional e pragmático. Tendo o sucesso como única preocupação, ele perdeu o sentido do mundo imaterial e utiliza Medeia como um fim para os seus planos de glória e poder. Ao explorar a estória de amor trágico encenada por Medeia e Jasão, o drama gira em torno da incompatibilidade entre duas culturas: a ancestralidade carregada por Medeia e o ceticismo de Jasão.

O filme se inicia com Jasão menino e sua educação ministrada por um Centauro, que aparece no início da película como um tutor de sua formação intelectual e moral. Nas cenas seguintes, vemos o crescimento de Jasão, junto a uma versão humana do Centauro. Esse ser mítico só volta a aparecer na película para Jasão um pouco antes de ele executar o plano de se casar com a filha do rei, Glauce, para conquistar o poder em Corinto. Nessa ocasião, ele alerta Jasão sobre as consequências possivelmente terríveis do ato de ele trair Medeia, que abandonou tudo o que conhecia por ele. Sem poder se intrometer efetivamente no destino das personagens, o Centauro, dividido em dois, parece tentar alertar Jasão sobre a sua insensatez e racionalidade enganosa, uma vez que a sua lógica mítica é incompreensível para ele, como a de Medeia. O Centauro se limita a perguntar a Jasão se ele realmente ama Medeia. Ele responde que sim, mas parece não desistir do seu plano de enganá-la, já que, em nenhum momento, realmente reflete sobre as palavras do seu mentor.

Figura 2: Cena do filme que retrata a natureza mítica envolvendo Jasão e Medeia (MATTAR, 2010)

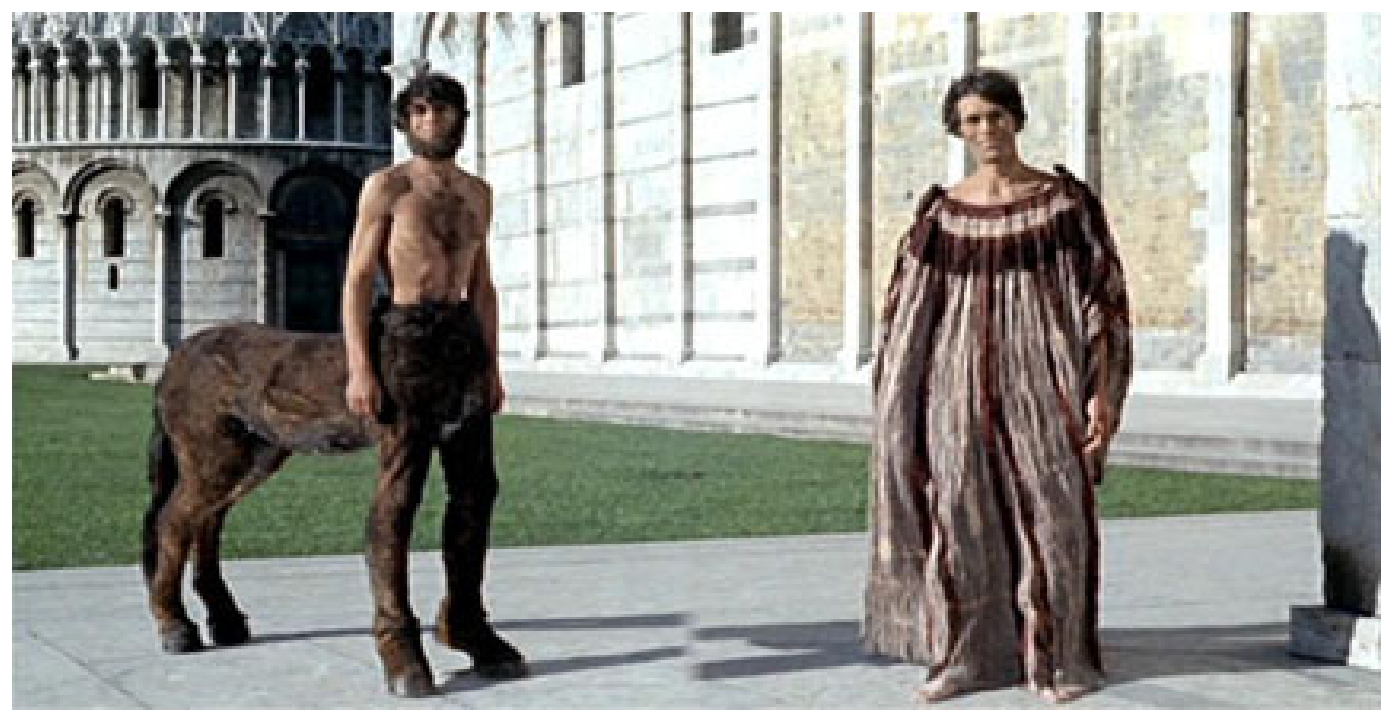

Fonte: http://joaomattar.com/blog/2010/o1/o8/medeia-medea-pier-paolo-pasolini/

Porém, no próprio prólogo do filme, centralizado na vida de Jasão com o Centauro, já podemos perceber a indiferença do menino. Logo no início da explanação do Centauro, 
Jasão já se mostra entediado (e acaba dormindo) enquanto ele afirma que tudo é sagrado e nada é natural, estando todas as coisas ligadas a um deus, portanto, nessa visão, nada seria apenas natureza. Jasão não reterá nada desses ensinamentos, recusando o estilo de vida da sacerdotisa, totalmente direcionado ao sagrado e ao metafísico.

Em seguida, já adulto, Jasão parte em sua busca para retomar o trono que lhe é de direito, ocupado pelo seu tio. Ao chegar ao local, ele lhe diz que renunciará ao seu reino se Jasão lhe entregar o Velocino de ouro, que é cultuado como divindade na terra de Medeia - descrita como um lugar habitado por um povo de hábitos bárbaros. Nesse ponto da narrativa, o espectador é levado a conhecer uma cerimônia sagrada de fertilidade, típica do povo de Medeia que habita a região da Cólquida (filmada na Capadócia, Turquia). A cena é representada por ritual primitivo, em que um jovem rapaz tem seu corpo pintado, amarrado e, logo em seguida, mutilado. Depois, seus membros e sangue são espalhados pelos integrantes da tribo de Medeia, inclusive para as crianças, os quais comemoram o feito divino. A fala "Dá vida à semente e renasce com a semente" (RYAN-SCHEUTZ, 2002, p. 27) é reproduzida por Medeia como parte do procedimento, fazendo referência à carne imolada do garoto como a semente do sacrifício que dá a vida. Em seguida, os habitantes do lugar gritam, dançam e festejam, pulando e cuspindo nos rostos da "realeza", composta por Medeia, seus pais e o irmão, os quais são presos em um lugar separado da horda alucinada e observam o rito, indiferentes e solenes. Essa cena lembra o ritual dionisíaco de desmembramento do corpo, chamado sparagmós, realizado pelas bacantes no culto ao deus, em que despedaçavam animais com as próprias mãos, quando manifestavam a potência divina. Com isso, representa na trama a alusão às cerimônias sagradas antigas, em cujos ritos o destroçamento significava simbolicamente a destruição de um "eu", um perder-se de si, a vivência de um sentimento místico de unidade primitiva.

Todo o processo do rito é inundado por uma música instrumental e por uma espécie de canção ritualística entoada pelos sacerdotes vestidos de preto, observados atentamente pelos habitantes da região que participavam da cerimônia: uns trajando capacetes com chifres e peles de animais em volta do corpo; outros usando máscaras feitas de palha e ossos de animais. Em seguida, o coração do jovem morto é levado a um local sagrado por um dos sacerdotes e, com o seu sangue, é banhada uma árvore sagrada. Com isso, todos os habitantes repetem a mesma ação, ungem o dedo no sangue batizado e se encaminham para banhar com os dedos besuntados em sangue as suas plantações, os trigais, e os animais, ou ainda enterrar em suas pequenas fazendas pedaços do corpo, como símbolo de fertilidade e de prosperidade para a colheita.

[...] podemos afirmar também que o país de Medéia, no filme de Pasolini, tem um papel de elemento tradutório da tragédia para o filme, servindo de elemento crítico e esvaziador de qualquer caráter melancólico quanto ao passado e aos seus "valores". Dessa forma, a língua de origem é trazida para o texto de chegada, mas de forma crítica, analisando a 
lacuna deixada por Eurípides quando omite o caráter mágico de Medéia, substituindo-o pelo "temperamento" dela. Pasolini, contrariamente, expõe como "origem" a dimensão mágica de Medéia. Se, por um lado, essa personagem está colocada por Eurípides numa modernidade grega, ela está traduzida por Pasolini para a nossa modernidade (MACIEL, 2011, n.p., grifos do autor).

Dessa forma, Maciel defende o propósito de Pasolini recuperar a origem mítica de Medeia, como forma de questionar a figura da mulher cruel dentro da visão contemporânea do mito, uma vez que, dentro dessa contextualização da figura de Medeia, no filme de Pasolini, os princípios morais que tradicionalmente estigmatizam a personagem são revelados como aqueles da sociedade ateniense, e não os da terra da feiticeira. Com isso, enquanto espectadores, somos convidados a refletir sobre os "valores" assumidos como "corretos" em nosso próprio julgamento sobre Medeia, a partir do entendimento de sua origem mítica: "Essas imagens, além da trilha sonora, são como uma anti-literatura necessária à realização da tradução de um texto trágico para o cinema, vale dizer, para um texto dramático moderno que desautomatize as leituras - literalmente falando - da peça trágica como texto literário” (MACIEL, 2011, n.p.).

Com isso, somos apresentados ao mundo da mulher e da sacerdotisa e suas ligações com o sagrado. Quando, na cena seguinte, Jasão invade o templo sagrado para roubar o Velocino de ouro, dá de cara com Medeia, que, ao olhar para ele, desmaia. Ao acordar, ela imediatamente pede ao seu irmão, Absirto, para ajudá-la a roubar o artefato e entregá-lo a Jasão, mesmo sabendo o que isso significaria para o seu povo. O seu irmão consente em executar a tarefa e os dois fogem com a lã sagrada, encontrando-se com Jasão e os argonautas no caminho. Porém, as pessoas da terra de Medeia percebem a ausência do Velocino e um grupo de guerreiros, liderados pelo seu pai, persegue os ladrões.

De repente, Medeia compreende que precisa atrasar o pai e os soldados, caso contrário seriam pegos. Assim, ela decide matar o próprio irmão, esquartejando o seu corpo em pedaços, da mesma forma que o garoto foi morto no ritual sagrado, no início do filme. Desse modo, o corpo do irmão é jogado pedaço por pedaço durante o percurso de fuga até o mar e Medeia atinge o seu objetivo, pois o comboio do pai interrompe o seu percurso a cada membro encontrado, para recolhê-lo, a fim de enterrar o filho depois. Na cena seguinte, Medeia e os argonautas são mostrados em alto mar, marchando para o reino do tio e, em seguida, o pai, juntamente com os guerreiros, volta com o corpo do filho mutilado para casa. Ao encontrar o corpo do filho mutilado, a mãe e as mulheres do lugar gritam e entoam preces e cantos desesperados.

Desde o primeiro momento que Medeia chega à terra de Jasão, percebemos a diferença entre os mundos das duas personagens. Quando Medeia, em função de suas conexões com o sagrado, corre assustada avisando Jasão e seus homens que falta um centro espiritual naquele lugar, tudo que eles fazem é rir dela. Veremos o choque entre as crenças dela e de Jasão, cuja 
relação passa a se deteriorar a partir do momento em que ele recebe a benção de Creonte, rei de Corinto, para desposar Glauce, sua filha, num acordo político-econômico entre os dois.

Mantida escondida em uma casa distante da cidade, Medeia fica enfraquecida e se sente humilhada. Essa condição lhe é imposta por Jasão, pois as pessoas de Corinto, incluindo o rei, tem muito medo dela por conta de sua magia. As amas que a acompanham, e também a amam, pedem para que ela se lembre de suas origens míticas e retome seu poder sagrado. Medeia diz que já não ouve as vozes do deus sol e da terra. Ao saber da traição de Jasão, porém, ela se enfurece e percebe que, para Jasão, ela não passa de um meio para alcançar um fim. Ele nunca esteve interessado na vida espiritual dela, pois sua ligação com Medeia era puramente utilitária, inclusive ele debocha, em vários momentos, dos apelos dela para que repense os seus atos. O espectador é levado a sentir empatia por essa mulher que renuncia a seu universo em nome de Jasão e no final percebe que este homem não pretende ser nada para ela.

A partir desse momento, Medeia bola uma artimanha para matar Glauce e se vingar do rei e de Jasão: ela convida Jasão para conversar e ela oferece trajes para a filha do rei, teoricamente em troca de poder assegurar a seus filhos uma estada segura na cidade, uma vez que Creonte quer expulsar Medeia e os meninos para fora do lugar. Glauce, que é descrita pelo filme como ingênua, vaidosa, e mesmo imprudente, pois não escuta o conselho de uma anciã para recusar os presentes, veste a túnica e sua morte é representada de duas maneiras: queimada viva pela roupa e enlouquecida pelo traje, pulando de um penhasco, ao que é seguida pelo pai, que, com remorso, também morre tentando salvá-la. Mas Medeia vai além: mata os três filhos que teve com Jasão e incendeia a casa deles, com um fogo que não se apaga, para que Jasão nunca possa enterrar os corpos das crianças. A última fala de Medeia, que é a que encerra o filme, é "Não! Não insista! É inútil! Nada mais é possível agora" (RYAN-SCHEUTZ, 2007, p. 71), o que remete à escolha ruim de Jasão e o consequente destino trágico das personagens.

Podemos verificar, no longa, a utilização de algumas técnicas de filmagem e de concepção cênica que vislumbram alcançar determinadas instâncias que ajudam a perfazer o caminho da "intriga” do fenômeno trágico. Segundo Ulysses Maciel (2011), Pasolini associa forma e conteúdo, pois traz para sua Medeia o mito (narrativa dentro da narrativa principal em que é contada a história do Centauro) e a língua de origem, a magia, através das cenas do país de Medeia. O sacrifício de Glauce, então, não seria uma mera vingança contra uma atitude "gregamente errada" de Jasão, mas uma questão de origem, da história de Medeia feiticeira e sacerdotisa, controladora das forças da natureza. Privilegia, em seu filme, o trágico não só nos conflitos internos da protagonista, mas também em uma espécie de embate entre a herança divina e selvagem da esposa de Jason e a sociedade de Corinto. Destaca, dessa maneira, a história de Medeia anterior ao argonauta Jasão, na Cólquida, onde era admirada como exímia feiticeira, neta do deus Sol e descendente da linhagem de Hécate, deusa lunar da vida e da morte, e em algumas versões do mito é também ligada à Circe, que na mitologia grega é caracterizada como uma poderosa feiticeira, ou deusa da magia e dos venenos. 
Ademais, a proposta de interpretação pasoliniana de Medeia aposta na desconstrução visual da massificação do olhar do espectador de cinema, segundo o paradigma da indústria cultural de Horkheimer e Adorno em Dialética do esclarecimento (1985), uma vez que torna imprescindível a apreensão dos fatos que desfilam diante dos olhos abismados do interlocutor. Esse processo foi alcançado por Pasolini pela apresentação de imagens não convencionais, dentre as quais terá papel importante os closes do rosto e dos olhos de Medeia, inclusive de perfil, nas suas caracterizações antiga e atual (no filme). Segundo Ryan-Scheutz (2007), o título original do filme seria "visões de Medeia", remetendo aos sonhos que a personagem tem, como também aos seus olhares. Seguindo o ponto de vista de Medeia, a câmera acompanha o perfil daquele corpo, da cabeça aos pés. Foi o próprio Pasolini que filmou a cena, na qual a silenciosa observação de Medeia reflete a expressão de sua subjetividade espiritual, presente desde o começo do filme. Através desse ritual privado, ela estabelece o corpo de Jasão como seu centro espiritual. A emoção é tão forte que ela acorda o homem para fazer amor com ele (isto é, fazer contato com o sagrado) (RYAN-SCHEUTZ, 2007, p. 30).

Figura 3 - Closes dos olhos de Medeia presentes no filme (OLIVEIRA, 2009)
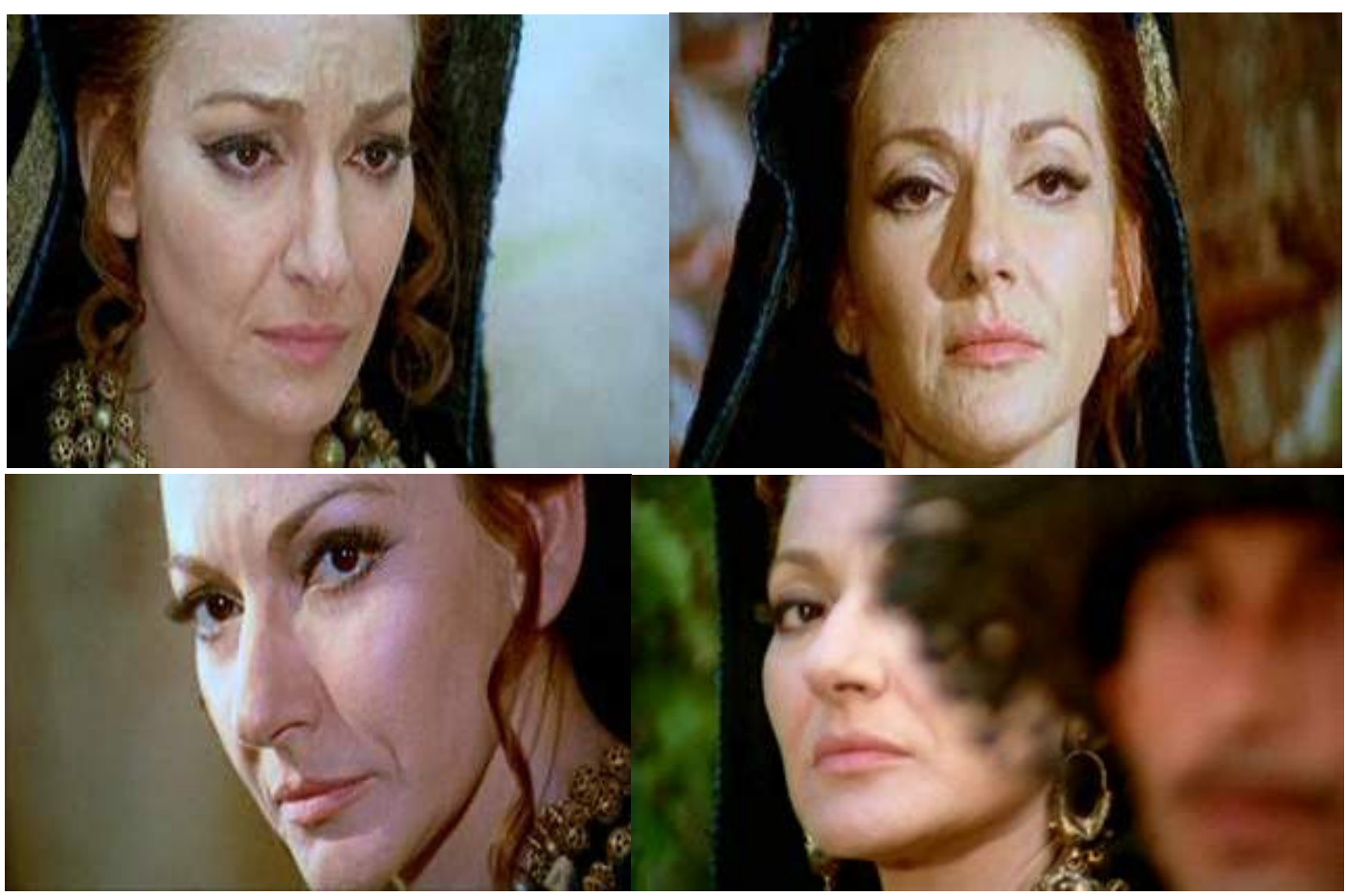

Fonte: https://cinemaitalianorao.blogspot.com/2009/08/as-mulheres-de-pier-paolo-pasolini-xii.html

Na segunda parte do filme, quando este, por algumas cenas, passa a imitar a tragédia de Eurípedes, também fica explícito que o comportamento de Medeia se deve à traição de Jasão. O caráter sempre grego da Medeia de Eurípedes é determinado pelo conflito que ela encerra, 
representado a partir de uma "análise consciente da experiência” (KITTO, 1990, p. 14). Nesse ponto, Pasolini preenche também uma lacuna deixada por Eurípedes, pois a sua heroína age - e isso fica bem claro pela introdução do signo da música bárbara e dos soldados nas cenas da casa de Medeia - por uma "justiça cara a deus" e para vingar-se "dos inimigos". A preparação do sacrifício de Glauce apresenta várias semelhanças com o sacrifício do jovem no país de Medeia: a música bárbara, o visual de Medeia, os soldados, as mulheres pintando as escadas.

Ainda segundo Maciel, cabe também estabelecer em que terreno se dará a tradução, uma vez que essa definição já está ancorada em características específicas do texto trágico de Eurípedes, como texto que escapa ao modelo aristotélico. Esse fato serve ao propósito do diretor Pier Paolo Pasolini, que seria o de ressaltar o comportamento trágico do homem moderno, explorando, para isso, as mudanças ocorridas na época de Eurípedes.

É como se o espírito Grego, durante este período, começasse a deslocar seu peso de um suporte para outro: da inteligência intuitiva baseada numa reflexão generalizada sobre a experiência humana e exprimindo-se através das da arte e das imagens tradicionais da mitologia, para uma análise consciente da experiência que se servia de novas técnicas intelectuais e era expressa, inevitavelmente, em prosa. É uma mudança que tem algo em comum com o nosso Iluminismo que começou durante o século dezessete; depois disso, na Inglaterra e até à renovação do movimento romântico, a poesia foi ou espirituosa ou lamentosa; na Grécia a poesia importante de grande estilo morre com Eurípides e com Sófocles. Estava ainda para vir a poesia requintada, mas já sem pretender sequer ocupar-se com o que mais importa; isto passou para a esfera dos filósofos (KITTO, 1990, p. 18).

\section{CONSIDERAÇõES FINAIS}

Para se entender a proposta de Pasolini para a caracterização de Medeia, e seu projeto ético-estético, é mister que se diferencie a Medeia de Eurípedes da do cineasta italiano. Segundo Maciel (2011), somente é possível para o homem moderno compreender a real dimensão dos conflitos contidos em Medeia se for feita uma tradução crítica das oposições narradas por Eurípedes, típicas da pólis grega, para as ideias expostas por Pasolini, que amplifica a importância da dimensão mítica da protagonista e desconstrói a razão dualista, introduzindo a concepção dialética do homem, de forma a compreender, como unidade, o conflito entre razão e natureza que ele encerra. Para Eurípedes, a tragédia remeteria a uma práxis do homem, em que o embate se realiza em seu coração, ou melhor, entre a razão e a paixão. Afasta-se, desse modo, da prevalência do mito e da medida aristotélica, dicotomizando o mundo dos homens e o mundo dos deuses. Sua Medeia, no entanto, ainda está muito arraigada a questões políticas 
da pólis grega, sendo a figura feminina da estrangeira representada sempre como a presença constante de um "mal" para a sociedade de Corinto.

Medéia é uma figura trágica, mas vimos que não se trata de uma heroína trágica aristotélica, na verdade, está possessa de uma natureza trágica apaixonada, absolutamente incontrolável tanto no amor quanto no ódio, o que a torna dramática não é a harmartía, mas é a mulher por inteiro. [Medéia] é trágica à medida que as suas paixões são mais fortes que a sua razão. [...] No entanto, não é uma heroína trágica, tal como temos compreendido o termo até agora. É demasiado extrema, demasiado simples. Não há aqui o estudo de um caráter, [...] porquanto a caracterização está, de qualquer modo, concentrada na paixão dominadora e a situação é manejada de forma a estimular ao máximo este fato (KITTO, 1990, p. 20).

Já a Medeia de Pier Paolo Pasolini remete a uma discussão mais profunda sobre o embate no interior do homem, sendo sua personagem representativa de uma origem ancestral e mítica, e, por isso, nem boa nem ruim, mas acima desses valores, opondo a racionalidade ingrata de Jasão à bárbara herança da preterida princesa da Cólquida: "A Medéia de Eurípides é grega, caracterizada pelo seu temperamento; a Medéia de Pasolini é sempre bárbara, embora se desconhecendo - 'uma ânfora cheia de conhecimento que não me pertence' -, mas a origem não se perde ('ainda sou a mesma')" (MACIEL, 2011, n.p.). Assim, podemos concluir que, ao deslocarem-se os sentidos presentes em um texto literário para uma tradução ou atualização cinematográfica, muitos pontos importantes deixados (entre)abertos no texto original podem ser reinterpretados e redimensionados, abrindo-se, assim, vários caminhos possíveis de leituras contemporâneas de escritos consagrados. O fascínio e terror exercido ao longo dos séculos por esta que é uma das mais famosas tragédias gregas conhecidas atualmente garante à obra e a seu autor a permanência viva em nosso imaginário cultural, conferindo ao mito da mulher cruel seu lugar de destaque na cultura ocidental. Para Pier Paolo Pasolini, verdadeiro "satélite" de seu tempo, o texto do mestre grego, bem como o mito em si, inspira-o a "apimentar" o diálogo cada vez mais crescente sobre o conflito existencial que o ser humano vem experimentando, perdido entre a razão e as paixões.

\section{REFERÊNCIAS}

ADORNO, T.; HORKHEIMER, M. A indústria cultural: o esclarecimento como mistificação das massas. In: Dialética do esclarecimento. Tradução de Guido Antônio de Almeida. Rio de Janeiro: Jorge Zahar, 1985.

ARISTÓTELES; HORÁCIO; LONGINO. A poética clássica. Introdução de Roberto de Oliveira Brandão; Tradução direta do grego e do latim por Jaime Bruna. 12. ed. São Paulo: Cultrix, 2005. 
BRANDÃO, Junito de Souza. Teatro grego: tragédia e comédia. Petrópolis: Vozes, 2. ed., 1984. EURÍPEDES. Medéia. Tradução de Miroel Silveira e Junia Silveira Gonçalves. São Paulo: Martin Claret, 2004.

FUSILLO, M. La Grecia secondo Pasolini. Firenze: La Nuova Italia, 1996.

HEGEL, Georg. Estética. Tradução de Álvaro Ribeiro e Orlando Vitorino. Lisboa: Guimarães Editora, 1993.

KIERKEGAARD, SørenAabye. O Conceito de angústia. Tradução de Álvaro L. M. Valls. São Paulo: Editora Universidade São Francisco, 2010.

KITTO, H. D. F. Tragédia grega: estudo literário. V. II. 3. ed. Tradução de José Manuel Coutinho e Castro. Coimbra: Armênio Amado, 1990.

LESKY, Albin. Do Problema do Trágico. In: A tragédia grega. Tradução de J. Guinsburg, Geraldo Gerson de Souza e Alberto Guzik. São Paulo: Editora Perspectiva. 2. ed, 1990.

MACHADO, Eduardo Pereira. O Trágico em Medéia. In: NEarco: Revista de Antiguidade, Núcleo de Estudos da Antiguidade, v. 1, n. 1 - Rio de Janeiro: UERJ/NEA, 2011.

MACIEL, Ulysses. Medéia, de Pasolini: uma tradução desconstrutora. Revista de Filologia da Uerj, 2011. Disponível em: http://www.filologia.org.br/ixcnlf/13/07.htm. Acesso em: 10 jul. 2020. MATTAR, João. Medeia (Medea) - Pier Paolo Pasolini, 2010. Disponível em: http://joaomattar. com/blog/2010/01/08/medeia-medea-pier-paolo-pasolini/. Acesso em: 10 jul. 2020.

NAZARIO, Luiz. Maria Callas em “Medea” - Arquivo Pasolini. Disponível em: https://lunazar. wordpress.com/2013/03/16/maria-callas-em-medeia/. Acesso em: 10 jul. 2020.

NIETZSCHE, Friedrich. O Nascimento da tragédia ou Helenismo e Pessimismo. Tradução de J. Ginsburg. São Paulo: Companhia das Letras, 1992.

OLIVEIRA, Roberto Acioli. As mulheres de Pier Paolo Pasolini (XII). Cinema Italiano - Ano 12, 2009. Disponível em: https://cinemaitalianorao.blogspot.com/2009/08/as-mulheres-depier-paolo-pasolini-xii.html. Acesso em: 10 jul. 2020.

PASOLINI, Pior Paolo. Lettera del traduttore (1960). In: Teatro. Milano: Meridiani Mondadori, 2001.

RYAN-SCHEUTZ, Colleen. Sex, the Self, and the Sacred. Women in the Cinema of Pier Paolo Pasolini. Canada: University of Toronto Press, 2007.

SCHELLING, Friedrich. Filosofia da arte. Tradução de Márcio Suzuki. São Paulo: EDUSP, 2001.

SCHOPENHAUER, Arthur. O mundo como vontade e representação. Tradução de M. F. Sá Correia. Rio de Janeiro: Contraponto, 2001.

SZONDI, Peter. Ensaio sobre o trágico. Tradução de Pedro Süssekind. Rio de Janeiro: Jorge Zahar, 2004. 
Medea. Direção e roteiro: Pier Paolo Pasolini. Produção: San Marco SpA (Roma), Le Films Number One (Paris) e Janus Film und Fernsehen (Frankfurt). Produtores: Franco Rossellini; Marina Cicogna. Filmado em maio-agosto 1969. Duração: 110 min.

Recebido para publicação em: 20 ago. 2020. Aceito para publicação em: 10 fev. 2021. 